Book Review:

Judul Buku: Islam Melayu VS Jawa Islam:

Menelusuri Jejak Karya Sastra Sejarah Nusantara

Penulis : Maharsi Resi

Penerbit : Pustaka Pelajar, Yogyakarta

Tahun : Cetakan Pertama, Februari 2010

ISBN : 978-602-8479-86-8

Tebal : $207+$ viii

\title{
MENGGALI MAKNA MITOS DALAM SASTRA DAN BUDAYA NUSANTARA
}

\author{
Yusdani \\ Staf Pengajar FIAI dan Peneliti pada Pusat Studi Islam UII. \\ Email: yusdani_msi@yahoo.com
}

\section{A. Pendahuluan}

Masyarakat Nusantara kaya akan tradisi lama yang telah mereka warisi dari nenek moyang mereka. Sampai sekarang masyarakat Nusantara masih dapat menikmati berbagai khazanah budaya yang tidak ternilai harganya. Salah satu peninggalan nenek moyang tersebut adalah dalam bentuk karya sastra, baik karya sastra yang hidup di kalangan masyarakat umum maupun karya sastra yang berkembang di istana.

Untuk menggali dan memahami berbagai khazanah budaya di atas, studi Islam Melayu dan Jawa Islam dalam sastra sejarah Nusantara, buku Islam Melayu Vs Jawa Islam: Menelusuri Jejak Karya Sastra Nusantara ${ }^{1}$ karya Maharsi Resi ${ }^{2}$ ini memfokuskan pada karya sastra sejarah Nusantara. Karya sastra sejarah ini menarik

1 Buku ini terdiri dari 5 bab. Bab I membahas Karya Sastra Sejarah Nusantara, Bab II menjelaskan Sinopsis Teks Sejarah Melayu dan Babad Tanah Jawi, Bab III mendeskripsikan Struktur Islam Melayu dan Jawa Islam, Bab IV menyoiroti Nilai Islam dalam Sastra Sejarah Nusantara, dan Bab V adalah Penutup.

2 Maharsi Resi adalah dosen tetap Fakultas Adab UIN Sunan Kalijaga lahir di Klaten, 31 Oktober 1971 menyelesaikan pendidikan S1 di Fakultas SastraUGM tahun 1995, S2 Antropologi UGM tahun 1998 dan S3 UIN Sunan Kalijaga Yogyakarta 2007. 
untuk dibahas karena isinya menceritakan tentang latar belakang dan asal-usul serta nenek moyang masyarakat Nusantara.

Studi atas sastra sejarah Nusantara merupakan kajian yang perlu diapresiasi karena sudah banyak penulis yang memberikan perhatiannya dan telah menulis karyanya dalam bidang ini. Dalam kajian ini, menunjukkan bahnwa Islam di wilayah Nusantara tidak hanya dipahami sebagai "agama", tetapi juga sudah merupakan identitas diri dalam kehidupan masyarakat.

Meskipun banyak ahli yang memperdebatkan tentang historisitas karya sastra jenis ini, namun karya sastra Nusantara ini bagi pendukungnya tetap diyakini sebagai sejarah nenek moyangnya. Bahkan yang lebih menarik lagi karya sastra sejarah Nusantara ini berkembang pada masa Islam di Nusantara. Oleh beberapa ahli menyatakan bahwa Islam merupakan pencetus lahirnya jenis karya sastra (sejarah) ini di Nusantara. Sudah tentu, unsur-unsur Islam yang terkandung dalam sastra sejarah sangat urgen dan menarik untuk dikaji lebih mendalam.

\section{B. Theoritical Framework}

Beberapa ahli menyebutkan bahwa Islam sebagai pencetus lahirnya jenis karya sastra sejarah di Nusantara. Sebagai karya sastra yang sebagian besar ditulis setelah datangnya agama Islam, karya sastra Nusantara banyak mengandung unsur-unsur Islam yang berkembang saat itu. Bahkan, dalam karya sastra sejarah Nusantara ini akan dapat dipahami bagaimana warna keislaman yang terdapat dalam suatu masyarakat pendukung karya itu.

Fakta tersebut itulah yang mendasari penolakan argumen bahwa Islam Nusantara diperkenalkan oleh para pedagang. Jika memang demikian, mengapa Islam baru kelihatan secara nyata pada abad 13. Padahal, wilayah Nusantara sudah dikunjungi oleh para pedagang Islam sejak abad VII dan VIII. Untuk menjawab persoalan mendasar tersebut, buku ini menawarkan sebuah kajian dengan pendekatan dan fokus yang berbeda jika dibandingkan dengan kajian-kajian sebelumnya.

Sebagaimana telah diketahui karya sastra sejarah Nusantara merupakan karya sastra yang unik. Bagi para pendukungnya karya sastra ini dianggap sebagai sejarah nenek moyangnya. Namun, bagi para peneliti sejarab masa lalu, karya sastra sejarah ini sama sekali tidak bernilai sejarah karena banyak sekali mitos dan legenda yang tidak mencerminkan tulisan sejarah yang logis. Atas dasar itu, penggunaan teori dan pendekatan yang tepat untuk menelaah sastra sejarah 
dapat menjadikan karya-karya sastra sejarah Nusantara ini menjadi penuh makna dan dapat diposisikan pada tempatnya. Dengan begitu, karya sastra sejarah ini dapat digunakan sebagai sumber sejarah jika dilakukan analisis yang kritis dan memadai, sehingga tidak berkesan bahwa karya sastra sejarab sudah final sebagai sumber sejarah. ${ }^{3}$

Sumber primer yang dijadikan referensi bahasan buku mengenai struktur Islam Jawa dan Islam Melayu ini yaitu teks Babad Tanah Jawi dan Sejarah Melayu. Teks Babad Tanah Jawi yang dianalisis dalam buku ini berasal dan naskah Babad Tanah Jawi versi Yogyakarta yang tersimpan di British Library London dengan Kode Naskah Add 12320. Berbeda dengan Babad Tanah Jawi edisi Meinsma, Babad Tanah Jawi versi Yogyakarta ini merupakan babad yang paling baik dijadikan sebagai sumber sejarah. ${ }^{4}$

Babad Tanah Jawi versi Yogyakarta tersebut terlepas dari masalah keragu-raguan tentang asal usul, penambahan maupun penerbitannya. Berdasarkan kolofon ${ }^{5}$ yang terdapat dalam naskah, Babad Kraton ditulis oleh Raden Tumenggung Jayengrat, salah seorang menantu Sultan Hamengkubuwana I di Yogyakarta pada 1703 tahun Jawa bertepatan dengan $1777 \mathrm{M}$.

Sedangkan teks Sejarah Melayu yang dikaji dalam buku ini berasal dan Naskah Sejarah Melayu yang ditulis oleh Tun Seri Lanang yang telah disunting oleh Abdullah bin Abdulkadir Munsi serta ditransliterasi oleh T.D. Situmorang dan A. Teeuw serta dibantu oleh Amal Hamzah. Naskah Sejarah Melayu ini sekarang tersimpan di Perpustakaan Nasional Jakarta dengan Kode KGB.

Meskipun edisi ini tidak sempurna, namun edisi ini cukup baik sebagai bahan kajian dan menjadi dasar dari semua terbitan selanjutnya. ${ }^{6}$ Pada kolofon yang terdapat pada bagian depan Sejarah Melayu dijelaskan bahwa teks ini ditulis oleh Tun Muhammad atau Tun Seri Lanang dan Negeri Malakat Batu Sawar atas perintah Yang Mulia Yang Dipertuan di Hilir, Sultan Abdullah Ma'ayah Syah Ibn Sultan Ala Jalla Abdul Jalil Syah yang berkerajaan di Johor.

3 Maharsi Resi, Islam Melayu VS Jawa Islam Menelusuri Jejak Karya Sastra Sejarah Nusantara (Yogyakarta: Pustaka Pelajar,2010), hal. 20.

4 Rickleft, "Consideration of Three Versions of the Babad Tanah Djawi with Except on the Fall of Madjapahit”, BSOAS vol. 35. 1972.

5 Kolofon adalah keterangan yang menunjukkan tentang identitas penulis, waktu dan tempat penulisan, tujuan penulisan naskah, dan lain-lain yang berhubungan dengan naskah. Kolofon biasanya terdapat di bagian awal atau akhir naskah.

6 A. Teew, Sejarah Melayu, (Jakarta: Djambatan, 1998), hal. xvi 


\section{Model Analisis Buku}

Dengan mempergunakan teori mitos dan karya sastra Levi Strauss, buku ini berusaha mengungkap makna cerita mitos yang terdapat baik dalam Babad Tanah Jawi maupun dalam Sejarah Melayu yang dihubungkan struktur budaya yang melahirkannya. Teks Babad Tanah Jawi dianalisis berdasarkan latar belakang budaya Jawa yang menjadi konteks lahirnya mitos yang terdapat dalam karya tersebut.

Sementara teks Sejarah Melayu dikaji dengan melihat konteks budaya Melayu pada masa teks itu ditulis. Sebagaimana telah diketahui bahwa analisis strukturalisme Levi Strauss mengenai mitos dipengaruhi analisis struktur bahasa yang dikembangkan oleh Ferdinand de Sausure, Jakobson, dan Nikolai Troubetzkoy. ${ }^{7}$

Menurut Levi Strauss, model struktur yang terdapat dalam bahasa mempunyai pola-pola yang hampir sama dengan mitos. ${ }^{8}$ Dalam hal ini mitos bukan sematamata merupakan cerita pelipur lara, tetapi merupakan cerita yang mengandung sejumlah pesan. Pesan itu tidak hanya terdapat dalam sebuah mitos tetapi tersimpan dalam keseluruhan mitos. Logika mi dihubungkan dengan struktur bahasa yang mempunyai hubungan sintagmatis dan paradigmatis.?

Dalam karya sastra sejarah Nusantara, mitos-mitos yang terdapat dalam cerita itu disampaikan oleh penulis naskah masa lalu, sedangkan penerima pesan itu adalah pembaca masa sekarang (masa kini). Dengan demikian hubungan pemberi pesan dan penerima pesan merupakan hubüngan yang sangat jauh dan bersifat satu arah. ${ }^{10}$

Oleh karena itu, pembaca karya sastra sejarah sebagai penerima pesan dalam mitos-mitos harus menggabung-gabungkan pesan itu sehingga pesan itu mempunyai makna. Dengan mengikuti alat analisis bahasa yaitu hubungan sintagmatis dan paradigmatis, pesan-pesan itu tersusun dan dapat dicari struktur pesannya yang ada di dalamnya.

Kajian terhadap Babad Tanah Jawi dan Sejarah Melayu dalam buku ini telah berusaha mengkombinasikan teori struktural Levi Strauss dengan analisis semiotik. Analisis semiotik digunakan untuk menafsirkan simbol-simbol dalam teks sastra sejarah. ${ }^{11}$

7 Heddy Shri Ahimsa Putra, Strukturalisme Levi Strauss: Mitos dan Karya Sastra, (Yogyakarta: Galang Press, 2001), hal. 90.

Levi Strauss, Structural Anthropology, (New York: Basic Book, 1976), hal. 160-161.

9 Maharsi Resi, Islam Melayu..., hal. 21.

10 Baca pernyataan Heddy Shri Ahimsa Putra, Strukturalisme Levi Strauss: Mitos dan Karya Sastra, (Yogyakarta: Galang Press, 2001), hal. 92.

11 Michael Riffatere, Semiotics of Poetr, (Bloomington \& London: Indiana University Press, 1978). 
Melalui empat tahap pemaknaan karya sastra, pertama puisi merupakan ekspresi tidak langsung yang menyatakan suatu hal dengan arti lain:, kedua pembacaan heuristik dan retroaktif atau hermeneutic; ketiga matriks, model, dan varianvariannya, dan keempat hipogram, maka simbol-simbol yang terdapat dalam kedua teks sastra sejarah tersebut dapat dimaknai secara komprehensif. Dengan kata lain penelitian ini menggunakan analisis simbolisme struktural. ${ }^{12}$

Pandangan Levi Strauss tersebut bertolak belakang dengan keyakinan Rassers bahwa ada kesatuan yang fundamental antara mitos dengan struktur kebudayaan masyarakat pendukungnya. Rassers sudah membuktikan hal itu dalam penelitiannya tentang cerita Panji dalam konteks biudaya Jawa. Hal inilah mungkin yang perlu dikritisi dari pendapat Strauss karena mitos lahir dari kebudayaan tertentu sehingga dalam memberikan makna juga harus disesuaikan dengan budaya yang melahirkan mitos itu sendiri. Mitos dan budaya masyarakat pendukungnya merupakan satu kesatuan yang tidak dapat dipisah-pisahkan sama sekali. ${ }^{13}$

Atas dasar itu, cerita mitos yang terdapat dalam Babad Tanah Jawa dan Sejarah Melayu dalam kajian buku ini diinterpretasikan sesuai struktur budaya masing-masing yang menjadi pendukung mitos itu. Gabungan analisis struktur dan simbol ini diharapkan dapat mengatasi kelemahan pada masing-masing pendekatan.

Dengan mengkombinasikan penggunaan analisis struktur dan simbol tersebut dapat menutupi kelemahan analisis struktur. Karena dengan hanya menggunakan analisis struktural sering dikatakan sebagai analisis yang kering karena hanya menemukan kerangka-kerangka atau pola-pola dan suatu fenomena. Dalam analisis struktur kadang-kadang penafsiran terhadap fenomena simbol kurang begitu mendalam, sehingga tidak sampai kepada makna yang sesungguhnya dan fenomena itu, sementara analisis simbol sering kali "kebablasan" sehingga keluar dari pakempakem objektivitas.

\section{Temuan dan Sanggahan}

Di sisi lain kajian buku ini menyanggah teori islamisasi ${ }^{14}$ yang sangat dominan dan telah diamini oleh kalangan sejarawan. Kebanyakan sarjana Barat yang

12 Maharsi Resi, Islam Melayu..., hal. 22.

13 Ibid, hal. 23.

14 Secara lebih rinci teori tentang masuknya Islam ke Indonesia, dapat dibaca Muhammad Iqbal, Hukum, Islam Indonesia Modern Dinamika Pemikiran dari Fiqh Klasik ke Figh Indonesia, (Tangerang: Gaya Media Pratama, 2009), hal. 32-36. 
dipelopori oleh van Leur memegang teori bahwa Islamisasi di Nusantara dilakukan oleb para pedagang Islam. Mereka sembari berdagang mengadakan dakwah di wilayah pantai Nusantara. Menurut van Leur motif ekonomi dan politik menjadi pendorong utama Islamisasi Nusantara. Para pengusaha pribumi akan mendapatkan keuntungan perdagangan ketika menerima Islam karena para pedagang muslim yang pada waktu itu menguasai sumber-sumber ekonomi. Demikian pula para penguasa pribumi berperan memberikan perlindungan kepada para pedagang internasional, dengan demikian mereka juga akan mendapatkan dukungan dan para pedagang muslim.

Teori van Leur di atas tidak sesuai dengan kisah yang terdapat dalam Babad Tanah Jawi dan Sejarah Melayu. Dalam teks Sejarah Melayu, Islamisasi Tanah Melayu pertama kali diperankan oleh tokoh Merah Silu yang kemudian menjadi raja Kerajaan Pertama Islam Samodra bergelar Malikul Saleh. Kisah lain menyebutkan Islamisasi Melayu dimulai oleh Raja Kecil Besar yang mendirikan Kerajaan Malaka bergelar Sultan Muhammad Syah.

Sementara Bahad Tanah Jawi mengisahkan Islamisasi di Jawa dimulai dan Raden Patah yang belajar Islam pada Sunan Ampel di Surabaya. Setelah menjadi Raja Demak, Raden Patah dengan dukungan para wali menyebarkan Islam di Nusantara. Keberhasilan Islamisasi Nusantara ini juga didukung oleh para ahli sufi yang berhasil meyakinkan para raja Nusantara. Dalam teks Sejarah Melayu dikisahkan bahwa Maulana Abu Bakar yang merupakan seorang ahli sufi dengan kitabnya Durrul Manzum mampu menarik minat masyarakat Melayu untuk memeluk agama Islam. Bahkan, kitab itu diterjemahkan dalam bahasa Melayu oleh seorang ulama kerajaan.

Fakta yang terdapat dalam karya sastra sejarah Nusantara ( buku) ini didukung oleh A. John yang menyatakan jika Islam Nusantara dibawa oleh kaum pedagang, mengapa Islam baru kelihatan secara nyata pada abad XIII. Padahal wilayah Nusantara sudah dikunjungi oleh para pedagang Islam sak abad .ke-VII dan VIll. ${ }^{15}$

John juga mendukung bahwa peran ulama sufi mempunyai andil dalam Islamisasi Nusantara. Kemampuan para sufi dalam menyajikan dan mengajarkan Islam dengan menekankan aspek harmonisasi dengan budaya setempat menjadi pendorong diterimanya Islam oleh masyarakat Nusantara.

Analisis buku ini terhadap Sejarah Melayu dan Babad Tanah Jawi juga mempertegas dan mendukung pendapat Azyumardi Azra bahwa berdasarkan

15 John A.H. "Muslim Mystic and Hietorical Writing", dalam D.G.E. Hall (ed.) Historians of South East Asia, (London: Oxford University Press, 1961). 
penelitian terhadap historiografi klasik dapat diambil beberapa kesimpulan berkaitan dengan penyebaran Islam Nusantara yaitu Islam dibawa langsung oleh para pendakwah profesional dan Arab, Islamisasi Nusantara mula-mula dipelopori oleh para penguasa, dan sebagian besar penyebar Islam datang ke Nusantara pada abad XII dan XIII M. ${ }^{16}$

Melalui karya sastra sejarah Nusantara buku ini dapat pula menjelaskan kenyataan bahwa budaya Melayu lebih "Islam daripada Melayu", sementara Budaya Jawa lebih "Jawa daripada Islam". Dengan kata lain, kisah dalam teks Sejarah Melayu lebih condong kepada sejarah Islamisasi Melayu (pengislaman Melayu), sementara Babad Tanah Jawi lebih condong ke Jawanisasi Islam (penjawaan Islam).

\section{E. Penutup}

Secara keseluruhan kajian yang terekam dalam buku ini secara akademis sangat kontributif dan kaya sumber. Selain itu, dalam kajian untuk mengungkap makna dalam sastra sejarah Nusantara buku ini telah berhasil menerapkan kerangka pendekatan, model dan desain analisis mendalam dengan mengkombinasikan sintagmatis paradigmatis dan konteks struktur budaya pendukung masing-masing mitos baik untuk Islam Melayu maupun Jawa Islam.

Hanya saja sebagai sebuah catatan kecil secara akademis atas model kajian seperti yang telah dilakukan dalam buku ini adalah dihadapkan pada realitas bahwa naskah sastra itu ditulis oleh penulis masa lalu dan merekam makna budaya sesuai dengan konteks masa lalu. Sementara pembaca naskah hidup dalam masa sekarang, dan bersamaan dengan itu pula struktur budaya masyarakat pendukung naskah itu sudah berubah. Dalam kaitan inilah dibutuhkan suatu kajian model alternatif dengan mempertimbangkan realitas empirik dan perubahan budaya masing-masing pendukung mitos itu.

\section{DAFTAR PUSTAKA}

A.H. John.1961. “ Muslim Mystic and Historical Writing “, dalam D.G.E. Hall (ed.) Historians of South East Asia. London: Oxford University Press.

A.Teew. Tanpa Tahun. Sejarah Melayu . Jakarta: Djambatan.

16 Azyumardi Azra, Jaringan Ulama Timur Tengah dan Kepulauan Nusantara Abad XVII \& XVIII, Edisi revisi, (Bandung: Mizan, 1994), hal. 12. 
Azra, Azyumardi.1994.Jaringan Ulama Timur Tengah dan Kepulauan Nusantara Abad XVII \& XVIII. Edisi revisi. Bandung: Mizan.

Iqbal, Muhammad. 2009. Hukum, Islam Indonesia Modern Dinamika Pemikiran dari Fiqh Klasik ke Fiqh Indonesia. Tangerang: Gaya Media Pratama.

Michael, Riffatere.1978. Semiotics of Poetr. Bloomington \& London: Indiana University Press.

Putra, Heddy Shri Ahimsa.2001. Strukturalisme Levi Strauss: Mitos dan Karya Sastra. Yogyakarta: Galang Press.

Resi, Maharsi.2010. Islam Melayu VS Jawa Islam Menelusuri Jejak Karya Sastra Sejarah Nusantara. Yogyakarta: Pustaka Pelajar.

Rickleft. 1972. "Consideration of Three Versions of the Babad Tanah Djawi with Except on the Fall of Madjapahit", BSOAS vol. 35.

Strauss, Levi. 1976. Structural Anthropology.Terjemahan. New York: Basic Book. 